\title{
Investigating the Cognitive Development of Slow Learners through Constructivist Geometry Games
}

\author{
Siti Juleha ${ }^{1}$, Sudirman ${ }^{2}$, Luthfiyati Nurafifah ${ }^{3}$, Ahmad Arifuddin ${ }^{4}$, Farid Gunadi ${ }^{5}$ \\ Department athematics Education, Universitas Wiralodra, Indramayu, Indonesia ${ }^{1,2,3,5}$ \\ Department of Madrasah Ibtidaiyah Teacher Education, Institut Agama Islam Negeri Syekh \\ Nurjati Cirebon, Indonesia ${ }^{4}$ \\ \{sudirman@unwir.ac.id $\left.{ }^{1}\right\}$
}

\begin{abstract}
This study aims to investigate the cognitive development of slow learners after practicing constructivist geometry games. In this qualitative case study, a total of 13 children from a PAUD in Indramayu participated. Of the 13 children, two children were categorized as slow learners based on the criteria of the characteristics of the slow learners in the questionnaire. The data in this study were collected through observation, interviews, documentation, tests, and questionnaires. The data were then analyzed qualitatively with the Bogdan and Biklen technique. The results showed that the application of geometry learning strategies with constructivist games can develop the coordination between eye and hand in constructing constructivists (blocks), increase children's vocabulary, develop children's social emotional skills, and foster children's religious and moral values. The percentage of overall learning completeness of slow learners also experienced a significant increase in each meeting, namely $0 \%$ at the first meeting, $50 \%$ at the second meeting, $100 \%$ at the third meeting, and $100 \%$ at the fourth meeting. Therefore, the application of geometry learning with constructivist games is effective in improving the cognitive abilities of slow learners.
\end{abstract}

Keywords: geometry; constructivist games; cognitive development; slow learner

\section{Introduction}

Every child has different cognitive abilities. This cognitive ability determines the children's achievement in school, and even determines their attitudes and actions towards their environment[1]. Dirgantoro [2] said that, when viewed from the learning activities in the classroom, students can be classified as quick learners and slow learners. Slow learners are those with special needs who cannot be recognized from their physical appearance but they require special educational services, namely special education programs that aim to help reduce the limitations of their life in society [3]. Slow learners have the cognitive ability below average, but they are not those with disabilities [4]. The IQ test scores of slow learners are between 70 and 90; and one among five children is a slow learner [5]. Dirgantoro [2] stated that the slow learners are always around us. Through this study, the researchers intend 
to help slow learners in improving their cognitive abilities.

One way to improve the children's cognitive abilities in learning geometry is by using learning media. As explained by Chauhan [6], slow learners are more able to understand concrete objects than abstract concepts so they have to use tools in the learning process. As shown in several studies, Jawati [7] uses the game of Ludo; Srianis et.al [8], Arifuddin [9] use the puzzle media; Mahmudati \& Indrawati [10] use the rainbow geometry media; Zaranis [11], Hanifah, et al. [12], Walid, et.al. [13], Sudirman, et.al. [14] use ICT (Information and Communication of Technology). Likewise, the wood block media can also be used for learning geometry at the early childhood level as done by Park et al. [15]. However, there has not been any learning using constructivist or block play media for slow learners at the early childhood level.

Constructivist games or blocks are visual media made of wood that can be used to develop the children's cognitive abilities [16]. This game employs blocks which have interesting shapes and colors. In addition to be attractive, constructivist games also employ concrete blocks with various geometric shapes. Those geometric shapes were initially only known by children in the abstract form. With the help of constructivist games, the children's thinking about the shape of those geometric objects becomes more concrete.

Based on this background, the purpose of this study was to investigate the cognitive development of slow learners after practicing the constructivist games. It is hoped that the use of constructivist games can improve the cognitive development of slow learners in their early childhood learning.

\section{Methodology}

This study employs a case study research design. This research design is used to help researchers avoid the data that have nothing to do with the research question. In total 13 students from one of the PAUD (early childhood education) schools in Indramayu participated in this study. Of the 13 students, two students were categorized as slow learners. The categorization was based on the criteria of the characteristics of slow learners by Marheni [17] which was made into a questionnaire by the researchers. The questionnaire was filled by classroom teachers and PAUD principals who actively participated in the learning. The object of this research is the constructivist play to facilitate the cognitive development of slow learners in their early childhood learning. Two children, one boy and one girl, participated in this study. Their average age was 5-6 years old.

The slow learners (student 1 / S1) and (student 1 / S2) have a normal body like children in general. Their ability to read and count was still very low. They were not able to count numbers 1 to 10 . In learning geometry, it was not easy for them to understand the names of geometric shapes such as squares. S1 and S2 can only understand it after being directed by the researchers repeatedly. If it's only been 1 or up to 5 times, S1 still could not understand it. Meanwhile, S2 could only understand after the researchers directed it more than 1 to 2 times. The concentration level of both S1 and S2 was still very low.

In this study, the researchers collected the data using observation, interviews, documentation, tests, and questionnaires. The observation was carried out to obtain data about the behavior, activities, actions, events, events, time, and feelings of the research subjects. This study uses perfect participant techniques to determine the application of geometry learning strategies with the help of constructivist games appropriate for slow learners and determine their impact on the cognitive development of slow learners at the early childhood 
level. The interview technique was used to collect in-depth data about their learning in this PAUD, the daily lives of slow learners, and the causes of children becoming slow learners. Using documentation techniques, the researchers provide the physical evidence of the research in the form of recordings, videos, and photos during observations, interviews, and during the slow learners' learning activities using constructivist games on geometry material. Documentations were also be used for the evaluation of the next teaching. Tests were used to measure the cognitive development of slow learners in learning geometry. The tests carried out in this study were in the form of oral tests which were assessed using oral test guides, children's worksheets (LKA), whereas the practice tests were assessed using a sheet check list. Researchers used a questionnaire to determine which children were categorized as slow learners. The questionnaire was filled by teachers in group A and PAUD principals who already understand the characters and abilities of children.

The data in this study were analyzed using the Bogdan and Biklen technique. The stages of data analysis according to Bogdan \& Biklen [18] are: (1) making a decision to narrow the study by changing the questions, (2) deciding the types of questions to be carried out, (3) developing analysis questions, (4) planning the data collection sessions, (5) making records as many as possible from observer comments, key informant and subject about the ideas generated, (6) writing field notes about events that occurred during the observation, (7) trying out questions on informants, (8) exploring reference sources, (9) playing with metaphors, analogies, and concepts, (10) use visual devices.

\section{Results and Discussion}

\subsection{The Application of Geometry Learning Strategies with the Constructivist Games}

Observations of the geometry learning for slow learners of early childhood level were carried out in schools. Before conducting the observations, the researchers sought information about these children by interviewing one of their families and visiting their homes to find out more clearly about their daily life, especially in learning activities. This research was conducted in four meetings, and at each meeting it was always ended with a test of the child's ability to understand geometry.

Each meeting in this study used the same strategy, applying the method of playing stories using constructivist games (figure 1) in the learning process. It was carried out outside the classroom so that children experienced the natural learning situations as they were playing without stress. Before learning began, the researcher first explained the procedures for playing constructivist games. Then, the researcher distributed constructivist games to each of the slow learners.

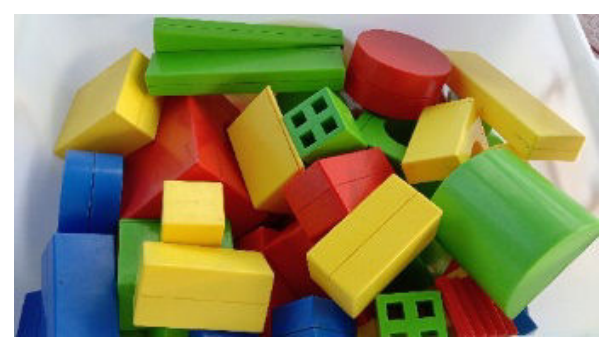

Fig. 1. Constructivist Games 
Different learning materials were given in each meeting. The learning materials for meeting 1: squares; meeting 2: triangles; and meeting 3: circles. Meanwhile, in meeting 4, we discussed all the three materials that had been previously taught. The followings are the geometry learning strategies done by slow learners at the early childhood level:

\section{a) Grouping Similar Geometric Shapes and Naming Geometric Shapes}

Slow learners sat in a circle, then one of the them held a geometric shape (meeting 1: squares ; meeting 2: triangles; meeting 3: circles, and meeting 4: those three geometric shapes). Then, the children passed the geometric shape to a friend beside him while singing a song. After the researcher gave the "stop" command, the children stopped passing. When they held the geometric shape, they were asked to name the geometric shape and its color. Then, they counted the numbers.

\section{b) Giving an Example and Describing the Shape of an Object Which is Similar to the Geometric Shape}

Children colored the picture of the geometric shape in each meeting. At meeting 1 (square): the picture similar to the square shape was colored yellow and the one that was not the same as the square was colored red. At meeting 2 (triangle): the picture similar to the the triangle shape was colored yellow and the one that was not the same as the triangle shape was colored red. At meeting 3 (circle): the picture similar to a circle was colored yellow and the one which was not the same as the circle shape was colored red. And at the fourth meeting (squares, triangles, and circles): the picture similar to the square shape was colored yellow whereas those resemble to the triangle shape were colored red. Meanwhile, the picture similar to the circle shape was colored blue. After that, the children answered verbally the questions from the teacher about the pictures that had already been colored.

\section{c) Drawing, Arranging, and Telling Stories About the Objects They Make}

The child drew geometric shapes, namely a square at meeting 1 , a circle at meeting 2 , a triangle at meeting 3 , and the three shapes at the fourth meeting. Then, the children arranged geometric shapes into several kinds of buildings according to their own ideas. An explanation of the types of buildings made by S1 and S2 from meeting 1 to meeting 4 can be seen in table 1 below:

Table 1. Miniature Buildings Made by the Slow Learners

\begin{tabular}{ccccc}
\hline \multirow{2}{*}{ Name } & \multicolumn{4}{c}{ Meeting } \\
\cline { 2 - 5 } S1 & $\mathbf{1}$ & $\mathbf{2}$ & $\mathbf{3}$ & $\mathbf{4}$ \\
& $\begin{array}{c}\text { Mosque, house, } \\
\text { and playground } \\
\text { Candle, }\end{array}$ & $\begin{array}{c}\text { Playground, bird's } \\
\text { house, and study } \\
\text { table }\end{array}$ & $\begin{array}{c}\text { House level, bed, } \\
\text { study table }\end{array}$ & $\begin{array}{c}\text { House, bridge, } \\
\text { mosque gate }\end{array}$ \\
S2 & $\begin{array}{c}\text { Candle, chair, and } \\
\text { mosque, and } \\
\text { house }\end{array}$ & $\begin{array}{c}\text { Birthday cake, } \\
\text { chair, and gadang } \\
\text { house }\end{array}$ & $\begin{array}{c}\text { Tower, rural } \\
\text { village, and rabbit } \\
\text { house }\end{array}$ \\
\hline
\end{tabular}

The miniature buildings made by S1 from meeting 1 to 4 can be seen in Figure 2, from left to right. 


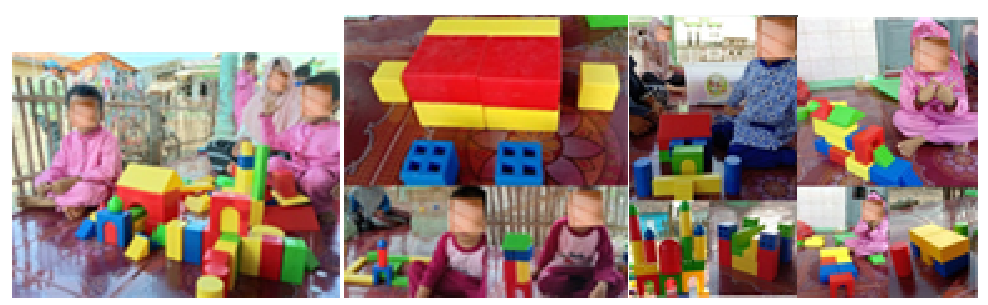

Fig. 2. Miniature buildings made by S1

The miniature buildings made by S2 from meeting 1 to 4 can be seen in Figure 3, from left to right.

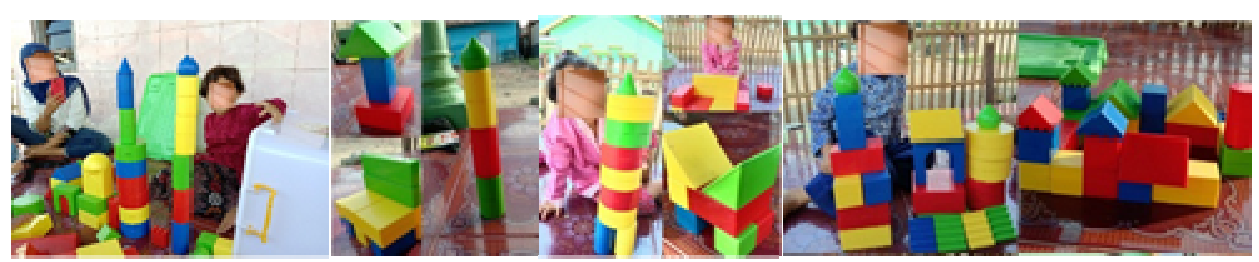

Fig. 3. Miniature buildings made by $\mathrm{S} 2$

Next, the children one by one told the shapes they arranged in front of the class. At meeting 1, S1 still could not explain the shape he made. Meanwhile, at the next meeting, S1 was able to explain even though at meeting 2 and 3 the researcher had to ask first. At meeting 4, S1 was able to explain without being asked by the researcher. At the first meeting S2 was still shy to explain the shape he made. However, at meeting 2 to 4 S2 was able to explain it.

Learning geometry at early childhood level, especially for slow learners, must be fun. The introduction of geometric shapes from an early age is very important for children, especially in fostering the children's interest in mathematics. Mathematics is closely related to the daily activities of human beings. Therefore, mathematics is very helpful for humans in understanding and overcoming social, economic as well as natural and cultural problems [19]. Dewi [20] revealed that learning geometry is important for children because they can analyze the characteristics of geometric shapes in developing mathematical arguments about geometric relationships. Jones [21] revealed that geometry is an extraordinary area of mathematics to teach and if geometry is taught properly it can allow more students to be success in mathematics. Clements \& Sarama [22] stated that for early childhood, the domains of geometry and spatial reasoning are important fields in mathematics learning.

Based on the findings of researchers, slow learners really enjoy learning using constructivist games. This is supported by their cognitive development. Then, the children are able to coordinate the eyes and hands in constructing constructivists (blocks). They also develop the their vocabulary, seeing from their ability to tell stories. In addition, the children's social emotional skills also develop. They became persistent and proud in their work. Children can arrange blocks into mosque. This can develop children's religious and moral values because they get more familiar with the place of worship of their religion.

Playing blocks according to Aliyah [23] is a constructive ability by making shapes or buildings using blocks with the aim of stimulating all aspects of development, as well as training children in solving problems by providing freedom of imagination, so as to create 
something new as a creative idea. This is in line with Sarama \& Clement's research [24] which states that learning geometry with building blocks can build strong mathematical foundations for learners at the early childhood level. The results of research by Dewi [20] also stated that playing blocks can improve children's understanding in recognizing geometric shapes.

\subsection{The Cognitive Development of Slow Learners at Early Childhood Level Cognitive after Practicing Constructivist Geometry Games}

The cognitive development of slow learners after practicing constructivist games overall increased. It can be seen from the aspect of knowing, understanding, and applying. Learning geometry in this study is said to be complete if it has reached the completeness criteria of $75 \%$. The cognitive conditions of the slow learners are as follows:

Table 2. Cognitive Condition of Slow Learners in Learning Square

\begin{tabular}{|c|c|c|c|c|c|c|}
\hline \multirow[b]{2}{*}{ No } & \multirow[b]{2}{*}{ Name } & \multicolumn{3}{|c|}{ Indicator } & \multirow{2}{*}{$\begin{array}{c}\text { Percentage } \\
(\%)\end{array}$} & \multirow{2}{*}{ Criteria } \\
\hline & & Knowing & Understanding & Applying & & \\
\hline & S1 & 0 & 2.50 & 4.44 & 23.13 & Not complete \\
\hline & $\mathrm{S} 2$ & 5 & 8.33 & 6.67 & 66.67 & Not complete \\
\hline
\end{tabular}

Table 2 above shows that the cognitive condition of slow learners at the first meeting with square material is still not complete. All children who take part in the research are still in the process of adapting to the material being taught. The percentage of completeness of learning at the first meeting is $0 \%$.

Table 3. Cognitive Conditions of Slow Learners in Learning Triangles

\begin{tabular}{|c|c|c|c|c|c|c|}
\hline \multirow{2}{*}{ No } & \multirow{2}{*}{ Name } & \multicolumn{3}{|c|}{ Indicator } & \multirow{2}{*}{$\begin{array}{c}\text { Percentage } \\
(\%)\end{array}$} & \multirow{2}{*}{ Criteria } \\
\hline & & Knowing & Understanding & Applying & & \\
\hline 1 & S1 & 5 & 5.83 & 8.89 & 65.74 & Not complete \\
\hline 2 & $\mathrm{~S} 2$ & 10 & 10 & 8.89 & 96.30 & Complete \\
\hline
\end{tabular}

Table 3 shows that the cognitive condition of slow learners at the second meeting with triangular material has increased. one child has reached completion in square material. The percentage of learning completeness at the second meeting is $50 \%$.

Table 4. Cognitive Conditions of Slow Learners in Learning Circle

\begin{tabular}{|c|c|c|c|c|c|c|}
\hline \multirow{2}{*}{ No } & \multirow{2}{*}{ Name } & \multicolumn{3}{|c|}{ Indicator } & \multirow{2}{*}{$\begin{array}{c}\text { Percentage } \\
(\%)\end{array}$} & \multirow{2}{*}{ Criteria } \\
\hline & & Knowing & Understanding & Applying & & \\
\hline 1 & S1 & 10 & 8.33 & 8.89 & 90.74 & Complete \\
\hline 2 & $\mathrm{~S} 2$ & 10 & 10 & 8.89 & 96.3 & Complete \\
\hline
\end{tabular}

From table 4, it can be seen that the cognitive condition of slow learners at the third meeting with circle material has increased more. All children have reached the completeness criteria in circle material. The percentage of learning completeness at the third meeting is $100 \%$. 
Table 5. Cognitive Conditions of Slow Learner Children in Learning Square, Triangles and Circles

\begin{tabular}{|c|c|c|c|c|c|c|}
\hline \multirow{2}{*}{ No } & \multirow{2}{*}{ Name } & \multicolumn{3}{|c|}{ Indicator } & \multirow{2}{*}{$\begin{array}{c}\text { Percentage } \\
(\%)\end{array}$} & \multirow{2}{*}{ Criteria } \\
\hline & & Knowing & Understanding & Applying & & \\
\hline 1 & S1 & 6.67 & 9.17 & 8.89 & 82.41 & Complete \\
\hline 2 & $\mathrm{~S} 2$ & 10 & 10 & 8.89 & 96.30 & Complete \\
\hline
\end{tabular}

This fourth meeting is made to determine the memory of slow learners who have been taught the square, triangle, and circle material. It can be seen from table 5 that the cognitive conditions of slow learners at the fourth meeting with material covering the three geometric shapes, namely squares, triangles, and circles have reached $100 \%$ completeness criteria.

Based on the results of the research described above, it shows that constructivist games can improve the children's cognitive abilities. Constructivist games can stimulate children to make buildings more attractive and have many variations. When children play with blocks, many findings are found. The construction form that they make has developed from simple forms to complex and clearly defined forms. There is an increase on the cognitive development of slow learners. Montolalu in Jawati [7] states that cognitive ability is a person's ability to think logically, critically, give reasons, solve problems and find causal relationships, such as mentioning, classifying, and differentiating things. The cognitive development experienced by children is closely related to the children's interest, courage, concentration and confidence in learning geometry with the help of constructivist games. Therefore, the success in the children's cognitive development is triggered by a pleasant atmosphere of learning while playing. A pleasant learning atmosphere can provide an excellent stimulus for brain function in processing information, so that it can increase the children's cognitive development.

\section{Conclusion}

Based on the results of the research described above, it can be concluded that the application of geometry learning strategies assisted by constructivist games can develop the children's eye and hand coordination in constructing constructivists (blocks), increase the children's vocabulary seen from their ability to tell stories, develop the children's social emotional skills such as feeling proud of their work, and develop the children's religious and moral values. There is a very significant increase on the cognitive development of slow learners. All children have achieved the completeness criteria in learning geometry. Therefore, the application of learning geometry with the help of constructivist games is effective in improving the cognitive abilities of slow learner children.

\section{References}

[1] G. W. Ladd, I. Ettekal, and B. Kochenderfer-Ladd, "Peer victimization trajectories from kindergarten through high school: Differential pathways for children's school engagement and achievement?," J. Educ. Psychol., vol. 109, no. 6, pp. 826-841, 2017.

[2] K. P. S. Dirgantoro, "Membelajarkan Matematika pada Siswa Lamban Belajar," Pedagog. J. Pendidik. Mat., vol. 3, no. 1, pp. 41-50, 2018.

[3] N. Khabibah, "Penanganan Instruksional Bagi Anak Lambat Belajar (Slow Learner)," Didakt. J. Pemikir. Pendidik., vol. 19, no. 2, pp. 26-32, 2017. 
[4] R. R. Borah, "Slow Learners: Role of Teachers and Guardians in Honing their Hidden Skills," Int. J. Educ. Plan. Adm., vol. 3, no. 2, pp. 139-143, 2013.

[5] D. Eastmead, "What is a Slow Learner?," www.memphisneurology.com, no. June. pp. $1-2,2004$.

[6] M. S. Chauhan, "Slow Learners: Their Psychology and Educational Programmes," Int. J. Multidiscip. Res., vol. 1, no. 8, pp. 279-289, 2011.

[7] R. Jawati, "Peningkatan Kemampuan Kognitif Anak Melalui Permainan Ludo Geometri Di Paud Habibul Ummi Ii,” Spektrum J. Pendidik. Luar Sekol., vol. 1, no. 1, pp. 250-263, 2013.

[8] K. Srianis, N. K. Suarni, and P. R. Ujianti, "Penerapan Metode Bermain Puzzle Geometri Untuk Meningkatkan Perkembangan Kognitif Anak Dalam Mengenal Bentuk," J. Pendidik. Anak Usia Dini Undiksha, vol. 2, no. 1, 2014.

[9] A. Arifuddin, S. Maufur, and Farida, "Pengaruh Penerapan Alat Peraga Puzzle dengan Menggunakan Metode Demonstrasi Terhadap Motivasi Belajar Siswa Pada Pembelajaran Matematika di SD / MI," J. Ilm. Sekol. Dasar, vol. 2, no. 1, pp. 10-17, 2018.

[10] R. Mahmudati and R. T. Indrawati, "Penerapan Rainbow Geometri dalam Pembentukan Konsep," vol. 6, no. 1, pp. 16-20, 2018.

[11] N. Zaranis, "The use of ICT in Preschool Education for geometry teaching," in Proceedings of the 10th international conference on computer based learning in science, learning science in the society of computers, 2012, pp. 256-262.

[12] N. H. Hanifah, A. Arifuddin, M. Walid, M. Padil, A. Bashith, and B. Busro, "Developing autoplay media based mathematics teaching materials for elementary school," J. Phys. Conf. Ser., vol. 1175, no. 1, p. 012265, 2019.

[13] M. Walid, A. M. Malik, A. Arifuddin, F. Uyun, and B. Busro, "Development of advanced micro devices media to enhance student concept understanding in thematic learning," J. Phys. Conf. Ser., vol. 1175, no. 1, p. 012176, 2019.

[14] S. Sudirman, P. Yaniawati, and R. Indrawan, "Integrating Local Wisdom Forms in Augmented Reality Applica-tion: Impact Attitudes, Motivations and Understanding of Geometry of Pre-service Mathematics Teachers," Int. J. Interact. Mob. Technol., vol. 14, no. 11, pp. 91-106, 2020.

[15] B. Park, J.-L. Chae, and B. F. Boyd, "Young children's block play and mathematical learning," J. Res. Child. Educ., vol. 23, no. 2, pp. 157-162, 2009.

[16] N. I. Musa, "Pengembangan Permainan Edukatif Balok pada Anak Usia Dini di Taman Kanak-Kanak Ciluuk Ba Makassar,” Universitas Negeri Makassar, Makassar, 2019.

[17] K. I. Marheni, "Art Therapy Bagi Anak Slow Learner," in Prosiding Temu Ilmiah Ikatan Psikologi Perkembangan Indonesia, 2017, pp. 154-162.

[18] R. C. Bogdan and S. K. Biklen, Qualitative Research for Education: An Introduction to Theories and Methods. 2007.

[19] S. Sudirman, Al. L. Son, and R. Rosyadi, "Penggunaan Etnomatematika pada Batik Paoman dalam Pembelajaran Geometri Bidang di Sekolah Dasar," IndoMath Indones. Math. Educ., vol. 1, no. 1, pp. 27-34, 2018.

[20] E. Y. P. Dewi, "Kemampuan Mengenal Bentuk Geometri Melalui Permainan Balok Anak Usia Dini," J. Early Child. Educ. Res., vol. 1, no. 1, pp. 32-45, 2019.

[21] K. Jones, Issues in the Teaching and Learning of Geometry. In: Linda Haggarty (Ed), Aspects of Teaching Secondary Mathematics: perspectives on practice. London: Routledge Falmer, 2002.

[22] D. H. Clements and J. Sarama, "Early childhood teacher education: the case of 
geometry," J. Math. Teach. Educ., vol. 14, no. February, pp. 133-148, 2011.

[23] S. Aliyah, "Hubungan Bermain Balok dengan Perkembangan Kognitif Anak Usia 4-5 Tahun di RA Miftahul Ulum Tahun Ajaran 2017/2018," in The Annual International Conference on Islamic Education, 2018, pp. 362-367.

[24] J. Sarama and D. H. Clements, "Building Blocks for Early Childhood Mathematics," Early Child. Res. Q., vol. 19, no. 1, pp. 181-189, 2004. 